\title{
Original article (full paper) \\ Assessment of motor coordination and dexterity of six years old children: A psychometric analysis
}

\author{
Olívia Souza Agostini \\ Federal University of Rio de Janeiro, Brazil \\ Lívia de Castro Magalhães \\ Alexandre Ferreira Campos \\ Federal University of Minas Gerais, Belo Horizonte, Brazil
}

\begin{abstract}
Motor coordination of six-year-old children was examined using the Assessment of Motor Coordination and Dexterity, AMCD (Avaliação da Coordenação e Destreza Motora - ACOORDEM), in order to verify test-retest reliability and investigate whether motor performance is influenced by gender, type of school and residence location. Eighty-five children were evaluated, and their parents and teachers completed questionnaires. For test-retest reliability, the AMCD was repeated with 10 children. Mann-Whitney and chi-square tests identified significant influence of sex, type of school and residence location in just a few of the test items. The test-retest reliability was moderate in the items performance, and good to excellent in the majority of the questionnaires' items. We conclude that some items should be revised and normative tables for the identification of motor delay could be created considering only the age variable. Future studies should continue the process of validating the AMCD instrument with the assessment of younger children.
\end{abstract}

Keywords: developmental coordination disorder, evaluation, reliability, test validity

Resumo - "Avaliação da coordenação e destreza motora de crianças de seis anos: Análise psicométrica." A coordenação motora de crianças de seis anos foi examinada através do teste de Avaliação da Coordenação e Destreza Motora, ACOORDEM (em desenvolvimento) com objetivo de avaliar a confiabilidade teste-reteste e investigar se o desempenho motor é influenciado pelo sexo, tipo de escola e local de moradia. Foram avaliadas 85 crianças e seus pais e professores responderam questionários. Para detectar a confiabilidade teste-reteste, a ACOORDEM foi reaplicada em $10 \mathrm{crianças.}$ Testes de Mann-Whitney e Qui-quadrado identificaram influência significativa do sexo, tipo de escola e local de moradia em apenas alguns itens. A confiabilidade teste-reteste foi moderada para os itens de desempenho, e de boa a excelente para maioria dos itens dos questionários. Conclui-se que alguns itens devem ser revisados e tabelas normativas de desempenho para identificação de atraso motor podem ser criadas considerando apenas a variável idade. Estudos futuros devem dar continuidade ao processo de criação do instrumento com avaliação de crianças mais jovens.

Palavras-chave: transtorno do desenvolvimento da coordenação, avaliação, confiabilidade, validade

Resumen - “Evaluación de la coordinación motora y la destreza de los niños de seis años de edad: Un análisis psicométrica." La coordinación motora en desarrollo del niños de seis años fue examinada por la Evaluación de la coordinación y destreza motora (Avaliação da Coordenação e Destreza Motora - ACOORDEM) con objetivo de evaluar la confiabilidad prueba-reprueba e investigar si el desempeño motor es influenciado por el sexo, tipo de escuela y sitio de la morada. Fueron evaluados 85 niños y sus padres y profesores respondieron cuestionarios. Para confiabilidad prueba- reprueba, la ACOORDEM fue aplicada de nuevo en 10 niños. Pruebas de Mann-Whitney y Chi-cuadrado identificaron significativa influencia del sexo, tipo de escuela y sitio de morada solo en algunos ítems. La confiabilidad prueba-reprueba fue moderada para los ítems de desempeño y de buena a excelente para la mayoría de los ítems del los cuestionarios. Se concluye que algunos ítems deben ser revisados y tablas normativas de desempeño para la identificación del atraso motor pueden ser creadas considerando solo la variable edad. Estudios futuros deben dar continuad al proceso de creación del instrumento con evaluación de niños más jóvenes.

Palabras clave: trastorno del desarrollo de la coordinación, evaluación, confiabilidad, validez 


\section{Introduction}

The assessment of motor function is useful for determining whether a child develops properly or has a delay that requires therapy or individualized assistance (Caçola, Bobbio, Arias, Gonçalves, \& Gabbard, 2010). A common motor problem that often goes unnoticed and ignored during specific motor assessment is Developmental Coordination Disorder (DCD). DCD includes discrete motor impairment, however causes major impact in school, family and social life of the DCD children. DCD affects more boys than girls, regardless of socioeconomic status or educational level (American Psychiatric Association, 2002). It is a very heterogeneous group regarding the extent of motor difficulty, and it is usually associated with other conditions such as Attention Deficit Disorder/Hyperactivity Disorder (ADDH), communication and nonverbal learning disorders (Chen, Tseng, $\mathrm{Hu}$ \& C Cermak, 2009).

These children often become the target of bullying, as they tend to avoid and/or exhibit poor performance in physical (Baerg, Cairney, Hay, Rempel, \& Faught, 2011; Li, Wu, Cairney, \& Hsieh, 2011 ) and group play activities, which limits the opportunities for practicing their skills and for social interaction (Cairney et al., 2005; Cairney et al., 2007; Schott, Alof, Hultsch, $\&$ Meermann, 2007). There is evidence of persistence of DCD throughout adolescence and adulthood, when, besides poor motor skills, there is a high incidence of poor executive functioning skills, social isolation, depression and anxiety (Kirby, Edwards, \& Sugden, 2011; Pratt \& Hill, 2011).

Considering the high incidence of DCD-estimated at approximately $5-6 \%$ of the child population (Blank, Smits-Engelman, Potatajko, \& Wilson, 2012) — and its impact on activity and participation at home, school and the community (Bart, Jarus, Erez, \& Rosenberg, 2011; Poulsen, Johnson, \& Ziviani, 2011), early diagnosis is important in order to provide appropriate treatment (Schoemaker et al., 2006). There are several tests for screening and diagnosing DCD. These tests were developed in children from varied countries (Magalhães, Rezende, \& Nascimento, 2004) and only a few have been translated and fully validated for the Brazilian children (Ramalho, Valentini, Muraro, Gardens, 2013; Valentini, Ramalho, Oliveira, 2014).

One of the most commonly used test in research (Schulz, Henderson, Sugden, \& Barnett, 2011) and recommended for the identification of DCD is the Movement Assessment Battery for Children - MABC-2 (Henderson, Sugden, \& Barnet, 2007). This is a screening test with good psychometric qualities (inter-rater and test-retest reliability, concurrent and construct validity). The MABC2 test was recently translated to Portuguese (Ramalho, Valentini, Muraro, Gardens, 2013; Valentini, Ramalho, Oliveira, 2014). However, the lack of further validation studies, cost and importation taxes may limit widespread use by clinicians.

Considering the importance of diagnosing and monitoring Brazilian children with motor coordination problems, there is a need for low cost assessment tools that provide a general view of the children's functioning within their daily environments. With this in mind, faculty members of the Occupational Therapy Department at the Federal University of Minas Gerais begun, in 2002, to work on the development of the Assessment of Motor Coordination and Dexterity, AMCD (Avaliação da Coordenação e Destreza Motora-ACOORDEM). The AMCD is a new motor test designed for children age four to eight. The AMCD is slightly different from the MABC-2, as intends to be a diagnostic assessment tool that allows triangulating information about motor skills, handwriting as well perspectives of parents and teacher in order to disclose a better picture of the children's activities and their participation at home and school (Magalhães, Nascimento, \& Rezende, 2004).

The AMCD adopts the perspective of the International Classification of Functioning - ICF (World Health Organization, 2001) and is designed to assess aspects of the body's function and structure (observational items of manual dexterity, fine coordination, coordination bilateral) in association with functional skills relevant to the participation at home and school (Parent's Questionnaire and Teacher`s Questionnaire in Activity and Participation). The AMCD follows stages methodology proposed by Benson and Clark (1982) for test development in occupational therapy. The three stages of item development (planning, construction and quantitative evaluation) were completed and included item analysis of the subscales of the test (Cardoso \& Magalhães, 2009; Cury \& Magalhães, 2006; Lacerda, Magalhães, \& Rezende, 2007). During the validation stage, Cardoso (2011) administered the AMCD's full version for the first time. The met the validity criteria during the assessment of motor performance and identification of DCD in children seven and eight years old. Employing the test with younger ages, in this study we examined the performance of six-year-old children and further investigated test reliability and validity. Studies with four- and five-year-old children are in progress.

To measure the test validity, it is important to investigate the effect of factors that may influence performance on the AMCD items. The literature indicates that there are differences in motor performance between boys and girls (Barnett, Van Beurden, Morgan, Brooks, \& Beard, 2009, 2010; Cardoso, 2011). In addition, motor experiences related to living in the countryside, in which freedom is greater and allows children to explore the environment and play in the streets, as well as the contrast between studying in public versus private schools, which generally limits opportunities of motor activities - , may also influence motor performance. These factors were herein investigated because they can influence the validity of the test scores, therefore interfering with interpretations of the test's results, as expressed in normative tables. Based on the literature and previous studies using the AMCD, we expect that boys will outperform girls in ball tasks, and girls will show better fine motor skills; we expect that countryside children and children from private schools would exhibit similar motor performance.

Inter-rater and test-retest reliability for individual items and subtests have been documented for the AMCD's subscales (Cardoso \& Magalhães, 2009; Cury \& Magalhães, 2006), but they have not been documented for the full test. The objectives of this study, therefore, were to: 1) describe the profile of motor coordination in six-year-old children, as defined by the AMCD's motor performance items, 2) investigate whether motor performance, as assessed by the AMCD's performance items, is influenced by gender, type of school (public or private) and 
residence location (capital - Belo Horizonte/MG and countryside - São João del-Rei/MG ${ }^{1}$ ) in order to validate decisions regarding test norms, 3) examine the AMCD's test-retest reliability (performance items and questionnaires), and 4) identify the AMCD test items that need revision or should be deleted. Other instruments besides the AMCD were used to document the frequency of DCD and related disorders in a non-clinical sample of Brazilian children, and characterize the sample by excluding children with neuromotor disorders. Motor assessments were also used to further provide concurrent validity in future studies.

\section{Method}

\section{Participants}

The study included 85 six-year-old children (72 to 83 months). They were recruited from public (44) and private (41) schools in São João del Rei - SJDR (43) and Belo Horizonte $\mathrm{BH}$ (42), 42 girls and 43 boys. Based on Cardoso (2011) and considering the statistical test to be used (i.e., effect size equal to 0.32 and $90 \%$ power), sample selection would require 62 children per age group (Cohen, 1988). However, we decided that the normative sample would be based in other motor tests (Bruininks \& Bruininks, 2005; Henderson, Sugden, \& Barnet, 2007), which included 76-80 six-year-old children.

The recruited children had no signs of physical, motor, visual or auditory impairments (visual correction with glasses was acceptable, but not hearing aid). Children born with gestational age $\leq 36$ weeks and weighing $\leq 2500$ grams or who were submitted to any kind of specialized motor therapy (physiotherapy and/or occupational therapy), with a history of school failure/ grade repetition, cognitive or learning disabilities, and those whose assessments could not be completed within seven days were excluded. Only children whose parents/guardians signed an informed consent letter were allowed to participate. Parents or guardians had to have at least primary education ( $4^{\text {th }}$ grade) for inclusion in the study.

The teachers of the children included in the sample also participated in the study. They had to be teaching the student for at least a month, and returned the questionnaires indicating their consent to be included in the study. To meet the sample size, 180 invitation/ informed consent letters were distributed and two public and 10 private schools collaborated with the study.

\section{Instruments}

The AMCD (Magalhães, Rezende, \& Cardoso, 2009) aims to detect motor coordination problems in four- to eight-year-old children, and uses items designed to assess the child's motor performance in three areas: 1) manual dexterity and coordination (16 items), 2) bilateral coordination and motor planning (26 items), and 3) activity and participation at home and school (parent's questionnaire with 54 items and teacher's questionnaire

\footnotetext{
${ }^{1}$ Belo Horizonte, the capital of the State, has about five million inhabitants in the great city area. São João del Rei is a medium size town, with 88.000 inhabitants.
}

with 30 items). Previous studies indicated adequate levels of reliability and validity (Cardoso, 2011; Cardoso \& Magalhães, 2009; Cury \& Magalhães, 2006; Lacerda, Magalhães, \& Rezende, 2007).

The Developmental Coordination Disorder Questionnaire - DCDQ-Brazil (Prado, Magalhães, \& Wilson, 2009) is a questionnaire for parents with 15 items to assess motor performance during movement, fine motor/writing and extensive coordination. The questionnaire is scored using a five-point Likert scale, with simple addition of scores to obtain the final result. According to data obtained in Canada (Wilson, Crawford, Kaplan, \& Roberts, 2006), scores below 46 indicate probable DCD in children ages 5-7 years old. Prado, Magalhães and Wilson (2009), in a crosscultural adaptation study that included Brazilian children of ages 7-12 years old, found test-retest reliability of 0.973 (ICC) and internal consistency (Cronbach's alpha) of 0.96 . The questionnaire was used to rule out more severe motor problems. The DCDQ was included for further validity studies in comparison with AMCD's questionnaire.

Movement Assessment Battery for Children, $2^{\text {nd }}$ edition MABC-2 (Henderson, Sugden, \& Barnet, 2007) was used as a screening test for identifying children with motor difficulties. The test covers the ages of 3-16 years old, and is divided into three age groups. In this study, we used the first one. The test consists of eight items: three manual dexterity, two ball skills (throw and catch) and three balance (static and dynamic). Children with scores below the $5^{\text {th }}$ percentile show obvious problems in motor coordination, the $6^{\text {th }}$ to $15^{\text {th }}$ percentiles indicate suspect cases, and children with scores above the $15^{\text {th }}$ percentile are considered to have normal motor performance. The test manual indicates test-retest reliability (r) of 0.80 for the total score and $0.77,0.84$ and 0.73 for the areas of manual dexterity, ball skills and balance, respectively (Henderson, Sugden, \& Barnet, 2007). The MABC-2 was used to characterize the sample and perform further validity studies.

Raven's Colored Progressive Matrices - RAVEN (Angelini, Alves, Custódio, Duarte, \& Duarte, 1999) intended to assess the intellectual development of 5-11-year-old children. The test consists of a series of drawings in ascending order of difficulty, with a missing piece that needs to be completed. The interpretation is made according to the following cognitive levels: I - intellectually superior, II - definitely above average in intellectual capacity, III - intellectually average IV - definitely below average in intellectual capacity, and V - intellectually deficient. The test was standardized for the Brazilian children and has acceptable test-retest reliability ( 0.69 to 0.85$)$ and high internal consistency (0.88 to 0.93 ) (Abdel-Khalek, 2005). RAVEN was used to exclude children with cognitive level below age expectation, i.e., levels IV and $\mathrm{V}$ according to the study criteria.

Swanson, Nolan and Pelham IV Scale-SNAP-IV (Swanson, Lerner, March, Gresham, 1999) is a screening questionnaire for ADHD based on the DSM-IV (American Psychiatric Association, 2002). The questionnaire has adequate psychometric properties (Bussing et al., 2008) and was translated into Portuguese by Mattos, Sierra Pine, Rodhe, and Pinto (2006). It consists of 18 statements that identify symptoms of inattention and hyperactivity/impulsivity, answered in four-point scale, according to what 
parents or teachers observe about the child's behaviour: "not a bit," "just a little," "quite" and "other." For interpretation, the number of scores "enough" or "too much" on items 1-9 and 1018 are counted. If there are more than six items, there are more symptoms of inattention or hyperactivity than expected. The SNAP-IV was filled out by teachers in order to document signs of attention deficit and hyperactivity, not for diagnostic purposes.

Economic Classification Criterion Brazil - ECCB (Brazilian Association of Research Companies, 2010) is a structured questionnaire used to indicate economic class based on information about the educational level of the head of the household and the number of service items (number of electrical appliances, cars, etc.) available in the house. Each item is scored on a scale of points and the sum is converted into categories that represent economic classes, ranging from A1 (very high) to E (very low).

\section{Procedures}

Schools that agreed to collaborate with the study forwarded to the parents an envelope containing the consent letter, a short questionnaire about the child's birth and developmental conditions and the parent's questionnaire, the ECCB, and the DCDQ-Brazil. The participants were randomly selected considering the study's inclusion and exclusion criteria. Children initially were evaluated with RAVEN and if they scored within the required cognitive levels (i.e., I, II or III), tests continued with the AMCD and MABC-2. In addition, the consent forms and questionnaires (SNAP-IV and teachers' questionnaire) were distributed to the teachers of these children.

The children were tested on the premises of their school (classroom or courtyard as available resources), at times defined by the teachers, supervisors and/or school board. The tests were administered individually by the first author and a graduate student, trained in assessment procedures, with good inter-rater reliability index on MABC-2 and the AMCD (intra class correlation - ICC - from 0.8 to 1.0 ). The assessment was divided into two days, with an average duration of one hour per day for each child. To examine the test-retest reliability 10 children selected by convenience repeated the AMCD within a four to seven days interval. Throughout the motor assessments the examiner observed children's responses to the items, especially regarding to extreme difficulty or discomfort while doing certain tasks. The study was approved by the Ethics Committee of the Federal University of Minas Gerais (ETIC 0647.0.203.000-10).

\section{Data analysis}

The statistical package SPSS version 17.0 was used for data analysis. Following descriptive statistics, as the Shapiro-Wilk test indicated that $82 \%$ of the quantitative items were not normally distributed, the analysis continued with the Mann-Whitney test followed by power analysis. Categorical data (i.e., type of school, social class and cognitive level) were compared by exact or asymptotic chi-square test with analysis of adjusted

Table 1: Medians and comparison by gender, type school and location for the AMCD: Coordination and manual dexterity quantitative items.

\begin{tabular}{|c|c|c|c|c|c|c|c|c|c|}
\hline \multirow[t]{2}{*}{ AMCD Items } & \multicolumn{2}{|c|}{ Gender } & \multirow[b]{2}{*}{$\mathrm{p}$ value } & \multicolumn{2}{|c|}{ School } & \multirow[b]{2}{*}{$\mathrm{p}$ value } & \multicolumn{2}{|c|}{ Location } & \multirow[b]{2}{*}{$\mathrm{p}$ value } \\
\hline & Girls & Boys & & Private & Public & & SJDR & $\mathrm{BH}$ & \\
\hline 1. Pegboard - preferred hand $\S$ & 15.00 & 14.50 & 0.179 & 14.00 & 15.00 & 0.364 & 15.00 & 15.00 & 0.467 \\
\hline 2. Pegboard - non-preferred hand $\S$ & 18.00 & 18.00 & 0.312 & 18.00 & 17.00 & 0.549 & 18.00 & 18.00 & 0.912 \\
\hline 3. Changing pegs between rows $\S$ & 21.00 & 21.00 & 0.994 & 19.00 & 22.00 & 0.297 & 19.00 & 23.00 & 0.651 \\
\hline 4. Lacing $\S$ & 33.00 & 30.50 & 0.881 & 30.00 & 32.00 & 0.016 & 31.00 & 32.00 & 0.258 \\
\hline 5. Coin in safe box - preferred hand $\S$ & 10.50 & 9.50 & 0.942 & 10.00 & 10.00 & 0.490 & 10.00 & 10.00 & 0.874 \\
\hline 6. Coin in safe box - non-preferred hand $\S$ & 12.00 & 13.00 & 0.628 & 12.00 & 13.00 & 0.158 & 12.00 & 12.00 & 0.873 \\
\hline 7. Separating playing cards $\S$ & 25.00 & 24.50 & 0.672 & 25.00 & 26.00 & 0.177 & 25.00 & 26.00 & 0.679 \\
\hline 8. Thumb/fingers preferred hand $\S$ & 10.50 & 8.50 & 0.483 & 10.00 & 9.00 & 0.366 & 10.00 & 11.00 & 0.851 \\
\hline 9. Thumb/fingers non-preferred hand $\S$ & 9.50 & 10.25 & 0.151 & 11.00 & 9.00 & 0.936 & 10.00 & 10.00 & 0.438 \\
\hline 10. Tracing straight \# & 0.00 & 0.00 & 0.257 & 0.00 & 0.00 & 0.726 & 0.00 & 0.00 & 0.111 \\
\hline 11. Tracing curved \# & 0.00 & 1.00 & 0.065 & 0.00 & 1.00 & 0.235 & 1.00 & 0.00 & 0.809 \\
\hline 12. Tracing butterfly\# & 7.00 & 7.50 & 0.053 & 7.00 & 7.00 & 0.106 & 6.00 & 7.00 & 0.214 \\
\hline 13. Figure copying- total score $\varnothing$ & 5.00 & 4.00 & 0.566 & 5.00 & 4.00 & 0.017 & 4.00 & 5.00 & 0.745 \\
\hline 14. Alphabet writing - time $\S$ & 77.00 & 84.00 & 0.212 & 78.00 & 86.00 & 0.009 & 82.00 & 88.00 & 0.515 \\
\hline 15. Copying sentence time $\S$ & 156.50 & 161.00 & 0.860 & 133.00 & 180.00 & 0.014 & 152.00 & 180.00 & 0.338 \\
\hline 16. Cutting straight \# & 0.00 & 0.00 & 0.540 & 0.00 & 0.00 & 0.902 & 0.00 & 0.00 & 0.402 \\
\hline 17. Cutting square\# & 0.00 & 3.50 & 0.103 & 0.00 & 2.00 & 0.760 & 1.00 & 0.00 & 0.964 \\
\hline 18. Cutting circle\# & 0.00 & 0.00 & $0.033 *$ & 0.00 & 0.00 & 0.656 & 0.00 & 0.00 & 0.491 \\
\hline 19. Cutting cat \# & 5.00 & 5.50 & 0.362 & 4.00 & 7.00 & 0.400 & 5.00 & 6.00 & 0.297 \\
\hline
\end{tabular}

$\S=$ time in seconds: lower scores indicate better performance; $\#=$ number of errors: lower scores indicate better performance; $\phi=$ number of hits: higher scores indicate better performance. Numbers in bold indicate significant differences; *medians are equal, but interquartile ranges are different. 
Table 2: Medians and comparison by gender, type school and location for the AMCD: Bilateral coordination and motor planning quantitative items.

\begin{tabular}{|c|c|c|c|c|c|c|c|c|c|}
\hline \multirow[t]{2}{*}{ AMCD Items } & \multicolumn{2}{|c|}{ Gender } & \multirow[b]{2}{*}{$\mathrm{p}$ value } & \multicolumn{2}{|c|}{ School } & \multirow[b]{2}{*}{$\mathrm{p}$ value } & \multicolumn{2}{|c|}{ Place } & \multirow[b]{2}{*}{$\mathrm{p}$ value } \\
\hline & Girl & Boy & & Private & Public & & SJDR & $\mathrm{BH}$ & \\
\hline Catching sandbag $\varnothing$ & 4.00 & 4.00 & 0.404 & 4.00 & 4.00 & 0.070 & 4.00 & 4.00 & 0.321 \\
\hline Bouncing ball $\phi$ & 4.50 & 5.00 & 0.004 & 5.00 & 5.00 & 0.687 & 5.00 & 5.00 & 0.787 \\
\hline Throwing the ball into the wall $\varnothing$ & 0.00 & 0.50 & 0.001 & 0.00 & 0.00 & 0.953 & 0.00 & 0.00 & 0.096 \\
\hline Bouncing tennis ball-two hands $\phi$ & 4.00 & 4.50 & 0.003 & 4.00 & 4.00 & 0.941 & 4.00 & 4.00 & 0.331 \\
\hline Bouncing tennis ball-preferred hand $\varnothing$ & 2.00 & 3.50 & 0.002 & 4.00 & 2.00 & 0.179 & 3.00 & 3.00 & 1.000 \\
\hline Catching tennis ball - two hands $\varnothing$ & 3.50 & 5.00 & 0.048 & 5.00 & 4.00 & 0.545 & 5.00 & 4.00 & 0.124 \\
\hline Catching tennis ball - preferred hand $\varnothing$ & 1.00 & 2.50 & 0.000 & 2.00 & 2.00 & 0.833 & 2.00 & 2.00 & 0.615 \\
\hline Labyrinth square preferred hand $\S$ & 4.00 & 4.00 & 0.342 & 4.00 & 4.00 & 0.521 & 4.00 & 4.00 & 0.408 \\
\hline Labyrinth square non-preferred hand $\S$ & 4.00 & 3.50 & 0.279 & 4.00 & 4.00 & 0.650 & 3.00 & 4.00 & 0.614 \\
\hline Labyrinth tree preferred hand $\S$ & 9.00 & 9.00 & 0.360 & 10.00 & 9.00 & 0.918 & 9.00 & 9.00 & 0.501 \\
\hline Labyrinth tree non-preferred hand $\S$ & 9.00 & 9.00 & 0.684 & 9.00 & 9.00 & 0.489 & 10.00 & 9.00 & 0.397 \\
\hline Prone-extension time $£$ & 23.50 & 1300 & 0.459 & 25.00 & 14.00 & 0.846 & 12.00 & 25.00 & 0.058 \\
\hline Supine-flexion time $£$ & 25.00 & 18.50 & 0.339 & 25.00 & 24.00 & 0.505 & 24.00 & 25.00 & 0.503 \\
\hline Balance EOR $£$ & 20.00 & 18.50 & 0.046 & 20.00 & 20.00 & $0.015 *$ & 20.00 & 20.00 & 0.098 \\
\hline Balance EOL£ & 13.50 & 15.50 & 0.267 & 20.00 & 13.00 & 0.053 & 13.00 & 15.00 & 0.128 \\
\hline Balance ECR $£$ & 4.50 & 3.00 & 0.538 & 3.00 & 4.00 & 0.451 & 6.00 & 3.00 & 0.167 \\
\hline Balance ECL $£$ & 5.00 & 3.00 & 0.183 & 6.00 & 3.00 & 0.082 & 3.00 & 5.00 & 0.737 \\
\hline Circuit time total $\S$ & 24.00 & 27.00 & 0.501 & 24.00 & 27.00 & 0.022 & 26.00 & 26.00 & $0.022 *$ \\
\hline Tandem number of steps $\varnothing$ & 6.00 & 6.00 & 0.480 & 5.00 & 6.00 & 0.636 & 6.00 & 5.00 & 0.064 \\
\hline Rabbit number of jumps $\varnothing$ & 5.00 & 5.00 & 0.352 & 5.00 & 5.00 & 0.736 & 5.00 & 5.00 & 0.905 \\
\hline
\end{tabular}

$\S=$ time in seconds: lower scores indicate better performance; $£=$ time in seconds: higher scores indicate better performance; $\#=$ number of errors: lower scores indicate better performance; $\phi=$ number of hits: higher scores indicate better performance. Numbers in bold indicate significant differences; *medians are equal, but interquartile ranges are different.

standardized residuals to locate the difference on the contingency tables. Test-retest reliability was calculated using ICC, whose indices can be interpreted as follows: poor correlation $(<0.40)$, moderate correlation (between 0.40 and 0.59$)$ good correlation (between 0.60 and 0.74 ) and excellent correlation (>0.75) (Cicchetti, 1994). For all analyses, significance level was set at 0.05 with $95 \%$ confidence interval. Task performance observation as well as the results of the item analyses (i.e., reliability), were used as indicators of items that need revision or should be replaced for five years old children and younger.

\section{Results}

The 85 children had a mean age of $77.91( \pm 3.17)$ months, mean birth weight of $3325.86( \pm 433.64)$ grams, $80(94.1 \%)$ of them had preference for the right hand, $77(90,6 \%)$ were enrolled in the first year and $8(9.4 \%)$ in the second year of elementary school.

Regarding the ECCB, two children (2.4\%) were in class A1, $15(17.6 \%)$ in class A2, $20(23.5 \%)$ in class B1, $18(21.2 \%)$ in class B2, $17(20.2 \%)$ in class C1, $12(14.1 \%)$ in class C2 and one $(1.2 \%)$ in class D. Performance on RAVEN was $23(27.1 \%)$, $30(35.3 \%)$ and $32(37.6 \%)$ of children in levels I, II, III, respectively. There was no difference between the groups in relation to the cognitive level ( $p=0.348)$, but significant difference was found on economic class $(p=0.001)$, with advantage for children on private schools.

According to the results of the SNAP-IV, in the total sample (85), nine $(10.6 \%)$ children showed signs of inattention, six (7.1\%) showed signs of hyperactivity/impulsivity, one $(1.2 \%)$ showed signs of ADHD combined, $68(80.0 \%)$ showed no signs of ADHD and one (1.2\%) questionnaire was not answered.

Regarding performance on the MABC-2, two children $(2.4 \%)$ had results indicating DCD, three (3.5\%) had suspect results and 80 children had normal performance. Based on the DCDQ-Brazil, 77 (90.6\%) children had typical performance. There was agreement on the results indicative of DCD in only two children based on the MABC-2 and DCDQ-Brazil, considering the $15^{\text {th }}$ percentile on the MABC-2 (a girl from Belo Horizonte's public school and a boy from São João del-Rei's private school) and only one child (boy), when considering the $5^{\text {th }}$ percentile. Based on the SNAP -IV, of the eight children $(9.4 \%)$ who showed signs of DCD on the DCDQ-Brazil, half of them had symptoms of inattention (3) and combination of inattention and hyperactivity (1). Among the five children $(5.9 \%)$ with suspect results or indicative of DCD on the MABC-2, one of them showed signs of inattention and other presented signs of combined ADHD on the SNAP-IV.

The medians and comparisons of the quantitative items of the AMCD by gender, school and place of residence, are specified in Tables 1 and 2. As the differences in qualitative items were even more discreet, we present only descriptive results. 
Table 3. Distribution of test-retest reliability indexes.

\begin{tabular}{lccccc}
\hline AMCD & $\begin{array}{c}\text { Total number } \\
\text { of items }\end{array}$ & $\begin{array}{c}\text { Poor } \\
\leq 0.40\end{array}$ & $\begin{array}{c}\text { Moderate } \\
0.40 \text { to } 0.59\end{array}$ & $\begin{array}{c}\text { Good } \\
0.60 \text { to } 0.74\end{array}$ & $\begin{array}{c}\text { Excellent } \\
\geq 0.75\end{array}$ \\
\hline Total (performance items) \# & 57 & $38.60 \%$ & $17.54 \%$ & $17.54 \%$ & $26.32 \%$ \\
Coordination and dexterity manual \# & 27 & $37.04 \%$ & $14.81 \%$ & $7.41 \%$ & $40.74 \%$ \\
Bilateral coordination and motor planning \# & 30 & $40.00 \%$ & $20.00 \%$ & $26.67 \%$ & $13.33 \%$ \\
Parents' questionnaire & 54 & $16.67 \%$ & $12.96 \%$ & $16.67 \%$ & $53.70 \%$ \\
Teachers' questionnaire & 30 & ----- & $3.33 \%$ & ----- & $96.67 \%$ \\
\hline
\end{tabular}

\# the number of items exceeds the total number of items in the AMCD because some items were counted more than once because they have scores for acuity, time and the use of each hand, plus the copying figures item have several sub-items.

Reliability indexes based on Cicchetti (1994).

Of the 57 items of the two areas of the AMCD, only nine items $(15.79 \%)$ showed significant differences with regard gender, eight quantitative items (Table 1 and 2) and a qualitative item, "hopscotch two feet to the side" $\left(\chi^{2}=7.935, p=0.019\right)$. In all items, boys performed better than girls, with the exception of the items "cutting a circle", "balance eyes open right side EOR" and "hopscotch two feet to the side."

Comparisons of type of school - public or private-, showed that only eight items (14.04\%) were significantly different, six quantitative items (Tables 1 and 2) and two qualitative - "copying the fish" $\left(\chi^{2}=4.989 ; p=0.026\right)$; "copying three circles" $\left(\chi^{2}=4.154, p=0.042\right)$. In all of these items children from private schools showed better performance.

Considering the school location, only four items (7.02\%) differed significantly with better performance for children from schools in the capital, three of which were qualitative: "drumming 4 " $\left(\chi^{2}=6.113, p=0.047\right)$; "prone-extension acuity" $\left(\chi^{2}=9.497\right.$, $p=0.009)$ and "supine-flexion acuity" $\left(\chi^{2}=5.701, p=0.017\right)$.

Power analysis, based on sample and effect sizes, showed values below 0.80 for all comparisons, except for the items "bouncing a tennis ball with preferred hand" (gender), "balance eyes open on right and left leg" (school type), and "sentence copy - time" (school type), that reached values of $0.98,0.87$, 0.95 , and 0.82 , respectively.

As for test-retest reliability, frequency rates of ICC in relation to the number of items analyzed are specified in Table 3. A total of $43.85 \%$ AMCD's items showed good to excellent ICC and considering the test's sections the following percentages were obtained: $48.14 \%$ in the area of coordination and manual dexterity, $40 \%$ in the area of bilateral coordination and motor planning, $70.37 \%$ in the parents' questionnaire and $96.67 \%$ in the teachers' questionnaire.

Observation conducted during test procedures indicated the number of pegs and coins for the hand manipulation tasks did not fit in the children's hands; some children were not able to jump the spaces between hopscotch squares; the alphabet and sentence copy tasks as well as the complex tracing and cutting tasks were too difficult for a number of children.

\section{Discussion}

Analysis of the performance profile of six years old children on the AMCD shows strengths as well as limitations in a number of items, which could be revised for further refinement of the test. Concerning validity issues, comparisons of performance considering gender, show few differences. This can be explained in terms of the developmental stage of children included in the study. According to Gallahue and Ozmun (2005), they are in the fundamental developmental stage, in which the motor patterns are not well defined or are in their initial or elementary stage, and therefore, there could be similarity between genders (Gorla, Duarte, \& Montagner, 2008).

Among the few items that showed differences, boys performed better in most ball skill items. Similar performance was also reported by Cardoso and Magalhães (2009) in their study with a previous version of the AMCD with Brazilian children. Moreover, using the current version to evaluate 7- and 8-year-old children, Cardoso (2011) found 11 items that showed significant gender differences and in all of them. Female children performed better than males, with the exception of the item "throw ball into wall," which was the only result that coincided with the present study.

As discussed in the literature, boys engage more physically and develop ball skills earlier than girls who tend to be better at manual dexterity tasks (Livesey, Coleman, \& Piek, 2007) and balance (Engel-Yeger, Rosenblum, \& Josman, 2010), as observed in this study. One of the balance items, jumping hopscotch, and the cutting a circle, seemed to be easier for girls, and the boys had superior performance in one ball task.

Giagazoglou et al. (2011), discussing issues related to the impact of gender on motor development and possible differences in abilities to perform certain tasks, concluded that, despite inconsistencies, norms for items with ball need not be separated by gender. Other authors found no significant gender differences when used the Test of Gross Motor Development 2 (Goodway, Robinson, \& Crowe, 2010) and the first version of the MABC (Giagazoglou et al., 2011). Van Waelvelde, Peersman, Lenoir, Smits Engelsman, and Henderson (2008) also did not recommend separate norms for boys and girls.

The creation of different standardized norms is also not recommended by Barnett (2008) because this process divides the sample and increases the likelihood of error. This is an important point to consider because, even though in the present study power was low for most comparisons, the sample size was calculated to be equitable or bigger than the age's normative sample for current motor tests. Future studies with the AMCD should continue exploring this aspect with younger children and with samples from other regions of Brazil, but inconsistencies in the differences identified with the present and previous studies with the AMCD suggest that it may not be necessary to develop standardized norms differentiated by gender. 
Comparing the performance by the type of school, only eight items against 13 in Cardoso's study (2011) showed significant differences, and in all of them children from private schools performed better than children from public schools. The items speed of the alphabet and sentence copy overlap in the two studies, confirming slower speed to copying letters or sentences for the public school children. It is well known that the environment and the encouragement offered can influence child's development and should be investigated (Oliveira, Magalhães, \& Salmela, 2008). The best physical structure and greater availability of specialized classes in private schools may have contributed to the better performance in some items.

Regarding the context of city and countryside, only four items showed significant differences favouring the capital (BH), which may have occurred by chance. Although children from small towns usually have more opportunities to play in the streets or in the backyards, this does not seem to influence motor performance, as measured by the AMCD items. Souza, Ferreira, Catuzzo, and Correa (2007) analyzing the performance of MABC in 240 children of seven and eight years-old from rural and urban parts of Manaus (Brazil) also found no significant differences between groups. Again, it should be stressed that for the majority of group comparisons power was low, indicating the need for increased sample size. Considering this limitation, we believe these results give preliminary support for creating the AMCD's normative tables only by age, as most tests do, without specifying either gender, type of school or location. These results, however, must be further examined with a full sample of 4-8-years-old children that shall complete the final normative sample for the test.

Considering reliability, only $44 \%$ of the performance items were considered of good to excellent retest reliability, but this percentage was much higher for the questionnaires. Based on the results of studies with the previous version of the AMCD, the data collected indicate limitations in the test-retest reliability of approximately half of the performance items. Cury and Magalhães (2006) tested the items of body balance in 66 Brazilian children, aged four, six, and eight years, with typical development. They found that $62.5 \%$ of the items reached levels of test-retest reliability above 0.80 and $35 \%$ of the items had values between 0.60 to 0.79 . However, Cardoso and Magalhães (2009), examining the test-retest reliability of the bilateral coordination and motor sequencing items in 84 children, aged four, six, and eight years, found that $45.7 \%$ of the items had acceptable indexes above 0.60 , a value that is close to the one found in this study (40\%).

Many factors may have contributed to the low test-retest reliability indexes reported in the present study. First of all, children were retested with the AMCD within a short period of time, which may have influenced the performance. According to Martins (2006), if the period between tests is too long, it may favours the acquisition of new skills generating a sub-estimation effect, but if the interval is too short, the results may be influenced by memory, contributing to super-estimation of the stability of the test. In the present study a different effect was observed due to the short interval between tests: the children did not show much interest in the retest. Moreover, since several items are frequently present in the daily routines, some children reported having trained them, which may have contributed to the low stability of the scores. The quality of the test environment may also have influenced the results, because given the conditions of some schools, where there were no specific assessment room, testing was conducted in noisy environments subject to external interference, which may have distracted the children.

Another factor to be considered, it is a too strict failure/stop criteria for the following the AMCD's performance items may have penalized 6-year-old children: putting coin in a safe box, copying sentence, alphabet writing, tracing butterfly, copying sentence, cutting the square, circle and the cat, throwing a ball to the wall, hopscotch and circuit. In some cases, children failed in one of the two trials, but managed to score on the other or failed in both situations, leaving missing data that compromised reliability analysis. The failure criterion for these items should be revised to allow younger children the opportunity at least try the item, even though spending more time or making more mistakes, such as not penalizing for pegs or coins that fall within the reach of the child, reducing the number of coins to fit in the hand of younger children, reducing the size of the spaces between the hopscotch squares, eliminating or simplifying the alphabet and sentence copy tasks, as well as the complex tracing and cutting tasks for children below six years of age. The scoring criteria for these items should be revised, especially considering the usage with 4- and 5-year-old children.

Finally, as the sample included only typically developing children, there was very little variability in scores. This limited range in the data of only 10 associated with the fact that reliability was analysed on the basis of raw scores, may also have contributed to the results. Indeed, slight variations in performance are expected, for example, in the time taken to place a few pegs in a board. However, as the analysis was based on the consistency of scores, these minor variations lead to reduction of the ICC. These variations can be minimized with the transformation of raw into standard scores, based on percentiles, which will be done in the future. Increasing the sample and standardizing the data in order to calculate a partial score for each subsection of the test may contribute to improve reliability indices. It is important to consider that most published tests do not report reliability of individual items, but rather on total and subdomains.

Regarding the questionnaires, the reliability was much better, especially for the teachers' questionnaire. The reliability of the teachers' questionnaire was better than the parents' questionnaire, possibly because the teachers had to respond to the questionnaire for several children in their class which may have contributed to better understanding the items. Moreover, the teachers' questionnaire is shorter and the questions are focused on the observation of activities that happen quite frequently in everyday classroom. This suggests that the parents' questionnaire can be revised to be shorter, more objective and focused on the daily routines at home, which will contribute to increased reliability.

Finally, considering the overall sample characteristics, even though the study was conducted with typically developing children, due to its design, we found $5.9 \%$ of children with motor coordination problems considering the $15^{\text {th }}$ percentile 
on the MABC-2, a result that is consistent with the prevalence of DCD established by the American Psychiatric Association (2002). It should be noted that the frequency of atypical motor performance was based on test results that still do not have cut-off scores defined for the Brazilian population (MABC-2 and DCDQ-Brazil). Also consistent with the literature (Martin, Piek, Baynam, Levy, \& Hay, 2010), among the children with probable DCD, as defined by the MABC-2 and DCDQ-Brazil, there were more signs of hyperactivity and inattention.

\section{Conclusion}

The very few significant differences between groups found in the performance of the AMCD items gives supports to the use of a single normative table, by age, but without distinction by gender, school type and school location (capital or countryside), for identification of motor delay. Future studies should further explore these issues in younger children and other regions of the country. Since sample size is an issue, the final format of the standardized results of the test should be based on detailed analysis with the full data set of 4-8-years-old children.

There is no evidence of problems with inter-rater reliability. However, little more than half of the performance items had poor to moderate test-retest reliability. The use of raw scores and inadequate test conditions may have influenced the results, which should be re-examined in future studies. The scoring criteria for some of the AMCD performance items should be revised so that younger children are able to perform them. Teachers' questionnaire had excellent reliability and some items, already responded by the teachers, can be eliminated from the parents' questionnaire, to make it more focused on the behaviours and tasks best observed at home.

This study identifies some limitations of the AMCD, indicating the need to adjust some items and criteria, which should be done before further studies. Detailed item analysis of the questionnaires should be conducted and, after item revision, future research should address the psychometric properties of the test with children four and five years-old. As a final goal, the reduction the AMCD number of items should be considered, as the detailed instructions and testing time of at least 60 minutes may limit its clinical use.

\section{References}

Abdel-Khalek, A. M. (2005).Reliability and factorial validity of the standard progressive matrices among Kuwaiti children ages 8 to 15 years. Percepual and Motor Skills, 101(2), 409-412. Retrieved from http://www.ncbi.nlm.nih.gov/pubmed/16383072.

American Psychiatric Association. (2002). Manual Diagnóstico e estatístico de transtornos mentais: DSM-IV-TR ( $5^{\text {th }}$ ed.). M. R. Jorge (Trans.). Porto Alegre, RS: Artes Médicas.

Angelini, A. L., Alves, I. C. B., Custódio, E. M., Duarte, W. F., \& Duarte, J. L. M. (1999). Matrizes Progressivas Coloridas de Raven: Escala Especial - Manual. São Paulo: CETEPP.

Associação Brasileira das Empresas de Pesquisa - ABEP. (2010). Critério de classificação econômica Brasil. Retrieved from http:// www.abep.org/novo/Content.aspx?ContentID=301.
Baerg, S., Cairney, J., Hay, J.; Rempel, L., \& Faught, B. E. (2011). Evaluating Physical Activity using Accelerometry in Children with Developmental Coordination Disorder in the Presence of Attention Deficit Hyperactivity Disorder. Research in Developmental Disabilities, 32(4), 1343-1350. dx.doi.org/10.1016/j.ridd.2011.02.009.

Barnett, A. L. (2008). Motor Assessment in Developmental Coordination Disorder: from identification to intervention. International Journal of Disability, Development and Education, 55(2), 113-129. Retrieved from http://www.informaworld.com/openurl?genre=article $\& \mathrm{id}=$ doi:10.1080/10349120802033436.

Barnett, L. M., Van Beurden, E., Morgtan, P. J., Brooks, L. O., \& Beard, J. R. (2009). Childhood motor skill proficiency as a predictor of adolescent physical activity. The journal of Adolescent Health, 44(3), 252-259. doi:10.1016/j.jadohealth.2008.07.004.

Barnett, L. M., Van Beurden, E., Morgtan, P. J., Brooks, L. O., \& Beard, J. R. (2010). Gender differences in motor skill proficiency from childhood to adolescence: a longitudinal study. Research Quarterly for Exercise and Sport, 81( 2), 162-170. Retrieved from http:// www.ncbi.nlm.nih.gov/pubmed/20527301.

Bart, O., Jarus, T., Erez, Y.; \& Rosenberg, L. (2011). How do young children with DCD participate and enjoy daily activities? Research in Developmental Disabilities, 32(4), 1317-1322. dx.doi. org/10.1016/j.ridd.2011.01.039.

Benson, J., \& Clark, F. A guide to instrument development and validation. American. (1982). Journal of Occupational Therapy, 36(12), 789-800. doi:10.5014/ajot.36.12.789.

Blank, R., Smits-Engelsman, B., Polatajko, H., \& Wilson, P. (2012). European Academy for Childhood Disability (EACD): Recommendations on the definition, diagnosis and intervention of developmental coordination disorder (long version). Developmental Medicine \& Child Neurology, 54(1), 54-93. dx.doi.org/10.1111/j. 1469-8749.2011.04171.x.

Bruininks, R.H., \& Bruininks, B.D. (2005). Bruininks-Oseretsky test of motor proficiency. (2th ed.) Circle Pine: American Guidance Service.

Bussing, R., Fernandez, M., Harwood, M., How, W., Garvan, C. W., Eyberg, S. M., \& Swanson, J. M. (2008). Parent and teacher SNAP-IV ratings of attention deficit hyperactivity disorder symptoms: psychometric properties and normative ratings from a school district sample. Assessment, 15(3), 317-328. doi: 10.1177/1073191107313888

Caçola, P. M., Bobbio, T. G., Arias, A. V., Gonçalves, V. G., \& Gabbard, C. (2010). Limitations of the Neurological Evolutional Exam (ENE) as a motor assessment for first graders. Revista Brasileira de Fisioterapia, 14(5). Retrieved from http://www.scielo.br/pdf/ rbfis/v14n5/024_10.pdf.

Cairney, J., Hay, J. A., Faught, B. E., Wade, T. J., Corna, L., \& Flouris, A. (2005) Developmental coordination disorder, generalized self-efficacy toward physical activity and participation in organized and free play activities. Journal of Pediatrics, 147(4), 515-520. doi:10.1016/j.jpeds.2005.05.013.

Cairney, J., Veldhuizen, S., Kurdyak, P., Missiuna, C., Faught, B. E., \& Hay, J. (2007). Evaluating the CSAPPA subscales as potential screening instruments for developmental coordination disorder. Archives of Diseases in Childhood, 92(11), 987-991. doi:10.1136/ adc.2006.115097.

Cardoso, A. A. (2011). Validade da Avaliação da Coordenação e Destreza Motora - ACOORDEM para Crianças de 7 a 8 anos de idade. (Doctoral Dissertation, Universidade Federal de Minas Gerais, Belo Horizonte). Retrieved from http://www.eef.ufmg.br/ mreab/documentos_new/Dissertpdf/TeseAnAmelia.pdf .

Cardoso, A. A., \& Magalhães, L. C. (2009). Bilateral coordination and motor sequencing in Brazilian children: preliminary construct validity and reliability analysis. Occupational Therapy International, 16(2), 107-121. dx.doi.org/10.1002/oti.273. 
Chen, Y. W., Tseng, M. H., Hu, F. C., \& Cermak, S. A. Psychosocial adjustment and attention in children with developmental coordination disorder using different motor tests. Research in Developmental Disabilities, 30(6), 1367-1377. http://dx.doi.org/10.1016/j. ridd.2009.06.004.

Cicchetti, D. V. (1994). Guidelines, criteria, and rules of thumb for evaluating normed and standardized assessment instruments in psychology. Psychological Assessment, 6(4). 284-290. Retrieved from http://psycnet.apa.org/index.cfm?fa=fulltext.journal\&jco$\mathrm{de}=$ pas $\&$ vol $=6 \&$ issue $=4 \&$ page $=284 \&$ format $=$ HTML $>$.

Cohen, J. (1988). Statistical analysis for the Behavioral Sciences. (2th ed). Hillsdale, NJ: Lawrence Erlbaum Associates.

Cury, R. L. S. M., \& Magalhães, L. C. (2006). Criação de protocolo de avaliação do equilíbrio corporal em crianças de quatro, seis e oito anos de idade: uma perspectiva funcional. Revista Brasileira de Fisioterapia, 10(3), 346-53. Retrieved from http://www.scielo. br/pdf/rbfis/v10n3/31955.pdf.

Engel-Yeger, B.; Rosenblum, S., \& Josman, N. (2010). Movement Assessment Battery for Children (M-ABC): Establishing construct validity for Israeli Children. Research in Developmental Disabilities, 31(1), 87-96. dx.doi.org/10.1016/j.ridd.2009.08.001.

Gallahue, D. L., \& Ozmun, J. C. (2005). Compreendendo o desenvolvimento motor: bebês, crianças, adolescentes e adultos. São Paulo: Ed. Phorte.

Giagazoglou, P., Kabitsis, N., Kokridas, D., Zaragas, C.; Katartzi, E., \& Kabitsis, C. (2011). The movement assessment battery in Greek preschoolers: The impact of age, gender, birth order, and physical activity on motor outcome. Research in Developmental Disabilities, 32(6), 2577-2582. dx.doi.org/10.1016/j.ridd.2011.06.020.

Goodway, J. D., Robinson, L. E., \& Crowe, H. (2010). Gender differences in fundamental motor skill development in disadvantaged preschoolers from two geographical regions. Research Quarterly for Exercise and Sport, 81(1), 17-24. Retrieved from http://www. ncbi.nlm.nih.gov/pubmed/20387395.

Gorla, J.I., Duarte, E., \& Montagner, P.C. (2008). Avaliação da coordenação motora de escolares da área urbana do município de Umuarama-PR Brasil. Revista Brasileira de Ciência e Movimento, 16(2), 57-65. Retrieved from portalrevistas.ucb.br/index.php/ RBCM/article/viewFile/1128/877.

Henderson, S. E., Sugden, D. A., Barnet, A. (2007). Movement assessment battery for children (MABC-2). (2nd ed). San Antonio: The Psychological Corporation.

Kirby, A., Edwards, L., Sugden, D. (2011). Emerging adulthood in developmental co-ordination disorder: parent and young adult perspectives. Research in Developmental Disabilities, 32(4), 13511360. dx.doi.org/10.1016/j.ridd.2011.01.041.

Lacerda, T. T. B., Magalhães, L. C., \& Rezende, M. B. (2007). Validade de conteúdo de questionários de coordenação motora para pais e professores. Revista de Terapia Ocupacional da Universidade de São Paulo, 18(2), 63-77.

Li, Y. C., Wu, S. K., Cairney, J., \& Hsiehc, Y. (2011). Motor coordination and health-related physical fitness of children with developmental coordination disorder: A three-year follow-up study. Research in Developmental Disabilities, 32(6), 2993-3002. dx.doi. org/10.1016/j.ridd.2011.04.009.

Livesey, D., Coleman, R., Piek, J. (2007). Performance on the Movement Assessment Battery for Children by Australian 3- to 5-year-old children. Child: Care, Health and Development, 33(6), 713-719. doi: 10.1111/j.1365-2214.2007.00733.x.

Magalhães, L. C., Nascimento, V. C. S., \& Rezende, M. B. (2004). Avaliação da coordenação e destreza motora - ACOORDEM: etapas de criação e perspectivas de validação. Revista de Terapia Ocupacional da Universidade de São Paulo, 15(1), 104-112.
Retrieved from http://www.revistas.usp.br/rto/article/view/13933.

Magalhães, L. C., Rezende, M. B., Cardoso, A. A. (2009). Avaliação da Coordenação e Destreza Motora - ACOORDEM - Versão 2. Unpublished manuscript.

Martin, N. C., Piek, J., Baynam, G., Levy, F., Hay, D. (2010). An examination of the relationship between movement problems and four common developmental disorders. Human Moviment Science, 29(5), 799-808. dx.doi.org/10.1016/j.humov.2009.09.005.

Martins, G. A. (2006). Sobre confiabilidade e validade. $R B G N-$ Revista Brasileira de Gestão de Negócios, 8(20), 1-12. Retrieved from 200.169.97.104/seer/index.php/RBGN/article/viewFile/51/44.

Mattos, P., Serra Pinheiro, M. A., Rodhe, L. A., \& Pinto, D. (2006). Apresentação de uma versão em português para o uso no Brasil do instrumento MTA-SNAP IV de Avaliação de sintomas de transtorno do déficit de atenção/hiperatividade e sintomas de transtorno desafiador e de oposição. Revista de Psiquiatria, 28(3), 290-7. dx.doi.org/10.1590/S0101-81082006000300008.

Oliveira, G. E., Magalhães, L. C., \& Salmela, L. F. T. (2011) Relação entre muito baixo peso ao nascimento, fatores ambientais e o desenvolvimento motor e o cognitivo de crianças aos 5 e 6 anos. Revista Brasileira de Fisioterapia, 15(2). dx.doi.org/10.1590/S141335552011000200009

Organização Mundial de Saúde. (2003). CIF: Classificação Internacional de funcionalidade, Incapacidade e Saúde. Centro Colaborador da Organização Mundial de Saúde para a Família de Classificações Internacionais (trans). São Paulo: EDUSP.

Poulsen, A. A., Johnson, H., \& Ziviani, J. M. (2011). Participation, self-concept and motor performance of boys with developmental coordination disorder: A classification and regression tree analysis approach. Australian Occupational Therapy Journal, 58(2), 95-102. doi: 10.1111/j.1440-1630.2010.00880.x

Prado, M. S. S., Magalhães, L. C., \& Wilson, B. N. (2009). Cross-cultural adaptation of the Developmental Coordination Disorder Questionnaire for brazilian children. Revista Brasileira de Fisioterapia, 13(3), 236-243. dx.doi.org/10.1590/S1413-35552009005000024.

Pratt, M. L., \& Hill, E. L. (2011). Anxiety profiles in children with and without developmental coordination disorder. Research in Developmental Disabilities, 32(4), 1253-1259. dx.doi.org/10.1016/j. ridd.2011.02.006.

Ramalho, M. H. S.; Valentini, N. C.; Muraro, C. F.; Gadens, R.; Nobre, G. C. (2013). Validação para língua portuguesa: Lista de Checagem da Movement Assessment Battery for Children. Motriz: Revista de Educação Física, 19(2): 423-431. Retrieved from: http://www.scielo.br/scielo.php?script=sci_arttext\&pi$\mathrm{d}=\mathrm{S} 1980-65742013000200019 \& \operatorname{lng}=\mathrm{en} \& \mathrm{nrm}=$ iso.

Schoemaker, M. M., Flapper, B., Verheij, N. P., Wilson, B. N., Reinders-Messelink, H. A., \& De Kloet, A. (2006). Evaluation of the Developmental Coordination Disorder Questionnaire as a screening instrument. Developmental Medicine and Child Neurology, 48(8), 668-673. doi: 10.1111/j.1469-8749.2006.tb01337.x

Schott, N., Alof, V., Hultsch, D., \& Meermann, D. (2007). Physical fitness in children with developmental coordination disorder. Research Quarterly for Exercise and Sport, 78(5), 438-450. Retrieved from http://www.ncbi.nlm.nih.gov/pubmed/18274216.

Schulz, J., Henderson, S. E., Sugden, D. A., \& Barnett, A. L. (2011). Structural validity of the Movement ABC-2 test: factor structure comparisons across three age groups. Research in Developmental Disabilities, 32(4), 1361-1369. dx.doi.org/10.1016/j. ridd.2011.01.032

Souza, C., Ferreira, L., Catuzzo, M. T., \& Corrêa, U. C. (2007). O teste $\mathrm{ABC}$ do Movimento em crianças de ambientes diferentes. Revista Portuguesa de Ciências do Desporto, 7(1), 36-47. Retrieved from www.fade.up.pt/rpcd/_arquivo/rpcd_vol.7_nr.1.pdf. 
Swanson, J., Lerner, M., March, J., Gresham, F. M. (1999). Assessment and intervention for attention-deficit/hyperactivity disorder in the schools. Lessons from the MTA study. Pediatrics Clinics of North América, 46(5), 993-1009. dx.doi.org/10.1016/S00313955(05)70168-1.

Valentini, N. C.; Ramalho, N. H., Oliveira, N. A. (2014). Movement Assessment Battery for Children-2: Translation, reliability, and validity for Brazilian children. Research in Developmental Disabilities, 35(3), 733-740. Retrieved from: http://www.sciencedirect. com/science/article/pii/S0891422213004721.

Van Waelveld, H., Peersman, W., Lenoir, M., Smits Engelsman, B., \& Hendersonj, S. (2008). The Movement Assessment Battery for Children: Similarities and differences between 4- and 5-year-old children from Flanders and the United States. Pediatric Physical Therapy, 20(1), 30-38. doi: 10.1097/PEP.0b013e31815ee2b2.

Wagner, M. O., Kastner, J., Petermann, F., \& Bös, K. (2011). Factorial validity of the Movement Assessment Battery for Children-2 (age band 2). Research in Developmental Disabilities, 32(2), 674-680. dx.doi.org/10.1016/j.ridd.2010.11.016.

Wilson, B. N., Crawford, S., Kaplan, B. J., \& Roberts, G. (2006). Further validation of the Developmental Coordination Disorder Questionnaire. Calgary Health Region and Department of Pediatrics, University of Calgary. Retrieved from dcdq.ca/pdf/ DCDQ_Summary_Report_2006.pdf

\section{Authors' note}

Olívia Souza Agostini, occupational therapist, is affiliated with the Department of Occupational Therapy, Federal University of Rio de Janeiro (UFRJ). http://lattes.cnpq.br/0494657158400371

Lívia de Castro Mgalhães, occupational therapist, is affiliated with the Department of Occupational Therapy, Federal University of Minas Gerais (UFMG). http://lattes.cnpq.br/1152950813115141

Alexandre Ferreira Campos, psychologist, doctoral student in psychology, Federal University of Minas Gerais (UFMG). http://lattes.cnpq. br/9027462043088276

\section{Corresponding author}

Lívia C. Magalhães

Departamento de Terapia Ocupacional

Avenida Antônio Carlos, 6627

Campus UFMG, Bairro Pampulha

Belo Horizonte 31270-901, MG, Brazil

Phone/Fax: (55-31) 3409-4790

E-mail: liviacmag@gmail.com

\section{Acknowledgements}

To parents, teachers, schools and children who participated in this study; to Lívia Paula F. Carvalho, undergraduate student research assistant who assisted in data collection, Raquel Etrusco Luz who helped in the revision of the manuscript, and for financial support by $\mathrm{CNPq}$, CAPES and FAPEMIG.

This work derives from a dissertation in the Graduate Program in Rehabilitation Sciences - UFMG. Part of this work was presented at the $10^{\text {th }}$ International Conference on Developmental Coordination Disorder, Ouro Preto, Brazil, 2013.

Manuscript received on June 17, 2013

Manuscript accepted on May 7, 2014

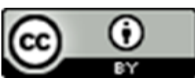

Motriz. The Journal of Physical Education. UNESP. Rio Claro, SP, Brazil - eISSN: 1980-6574 - under a license Creative Commons - Version 3.0 